\title{
Developing church leaders in Africa for reliable leadership: A Kenyan perspective
}

\begin{abstract}
Reliable leadership is an indispensable component of any progressive society. The rapidly changing African society with its numerous challenges calls for reliable leadership. The Church which is the most trusted institution has failed to offer this reliable leadership to the African society. In spite of the fact that the Church in Africa is experiencing tremendous numerical growth, she has failed to produce enough leaders and the few available are not well-equipped to meet the needs of the African people in this century. If the Church in Africa hopes to be relevant to the African society, she has to re-think her training system. She must produce leaders who can be relied on by the African people. This is only possible if she produces enough wellqualified leaders to match the rapidly growing African Church and society.
\end{abstract}

\section{INTRODUCTION}

Africa needs reliable leadership today more than any other time before. Christian leadership just as the political leadership has become one of the major challenges facing the African society today. The twenty-first century as anticipated has come with numerous challenges, whereby Africa just as the rest of the world is undergoing rapid socio-economic and political changes, yet the leaders (both in the church and political spheres) are not able to adjust to these changes. New scientific and technological inventions have made the society more complex than it has ever been. The youths are the ones mostly affected by these changes as they wrestle to become 'modern' in a society where there are few role models. In face of these challenges, church leaders have been relied upon by the people to offer solutions but unfortunately this seems not to have happened. It can be argued in this paper that the Church which is one of the most reliable institutions in Africa seems not to have produced leaders who can be relied on by the church and society. Hendriks (2006) denotes that the churches in Africa have by far the highest level of public trust and as such can contribute immensely towards Africa's moral regeneration and towards the development of African leadership.

One question we may need to ask is whether the people in Africa can trust church leaders the same way they trust the Church as an institution. This paper mainly focuses on Kenya where the public trust in church leadership is slowly fading away as witnessed in August 2010. Although most of the church leaders in Kenya were against the new constitution (http://naibobi. wantedinafrica.com/news; http://allafrica.com/stories), the majority of the church members voted for it (Kenya Gazette, August 2010). ${ }^{1}$ According to the poll conducted by Silo Breaker Star

1. When the New Constitution was drafted in 2010, the Church Leaders urged their members to reject it on the ground that it did not allow religious equity due to the provision it made for the Islamic Courts and also the clause allowing doctors to terminate pregnancy in the event that the mother's life was in danger. They argued that this was an indirect way of legalizing abortion in Kenya. The church leaders mobilized their followers to vote 'No' to reject the New Law. When the Referendum was held on 4 August 2010, the new constitution was ratified by over $67 \%$ of the votes cast. According to the Kenya Gazette (August 
after the referendum on the constitution held in Kenya on 5 August 2010, about 58 per cent of Kenyans interviewed confessed to have lost trust in their church leaders (Silo Breaker Star 2010). This may be an indication of what is happening in the whole of Africa. The church in Africa is physically a growing institution and one wonders why such a trusted organization has not been able to produce trusted leaders.

\section{LEADERSHIP NEEDS FOR A GROWING KENYAN CHURCH}

The Church in Kenya just like in the rest of Africa is a numerically growing Church. Hendriks (2006) asserts that the one success story in Africa especially after the colonial period is the growth of the Christian Church. The Christian world's centre of gravity is currently shifting southwards to Africa, Asia and Latin America (Jenkins 2002). We however need to note that this numerical/ physical growth does not correspond to the spiritual or even theological growth. In other words, the problem statement is that the church in Africa is growing numerically but not spiritually or theologically. This implies that the Church in Africa is expanding in terms of numbers, but its quality remains questionable. In the year 2005, the author studied the Anglican Church in Meru in Kenya and the findings had a lot to tell about the general Church in Africa. He found the Anglican Church in Meru was growing at a tremendously high rate, but the kind of Christianity that was being practiced was very superficial with many church members being Christians on Sundays but retreating to their traditions on other days (Nkonge 2005:80). Might this be an indication of what the entire Africa is experiencing? In this paper, we are however not concerned with the spiritual growth but with the theological output (although spiritual matters are not separate from theological issues), whereby we shall be asking whether the rapidly growing Kenyan church has managed to produce church leaders at the same rate so as to match this numerical growth. So to speak, reliability deals with the quantity and quality. In this case then, has the church in Kenya or even the whole of Africa produced enough and well-trained church leaders who can be relied upon to offer leadership in this century which has many challenges?

The Church in Kenya has been experiencing a tremendous growth since its inception in the nineteenth-century. Christianity was started in Kenya by the European missionaries who had come under the auspices of various Missionary Societies including, the Church Missionary Society (CMS) which started the Anglican Church in 1844, the Holy Ghost Mission (HGM) which planted the Catholic Church in Kenya in 1860, the United Methodist Mission (UMM) which started the Methodist Church in 1862 and the Church of Scotland Mission (CSM) which started the Presbyterian Church in 1891(Mumo 1997: 1). All these churches were started on the East African coast. Earlier efforts by the Portuguese to evangelize East Africa in the sixteenth-century did not bear much fruit as they were not very keen to put in practice what they propagated. While they emphasized that a Christian should have good morals, they had very rotten morals where some of them kept African concubines and most of them concentrated on commerce than on the gospel (Nkonge 2005: 24). As a result their religion had no impact in the lives of the Africans and in 1729 they were expelled from the East Africa by the Arabs (Baur 1990:23). From then henceforth, East Africa remained for a long time without any Christian presence until the Mission Societies in Europe started to send missionaries in the nineteenth-century (Waruta 1989:83).

David Barrett (1982:32) in the 1980's showed that Christianity in Kenya was the most preferred religion by the majority of Kenyans hence growing very fast. He estimated that Christians constituted $73 \%$ the Kenya's population and projected that this figure would rise to about $81.9 \%$ at the beginning of the twenty-first century. Barrett's projections are viable because according

2010), 6, 092, 593 Kenyans voted in the favor of the new law, while 2,795, 059 were against. 
to the 2009 Kenya's population census released last year, about $82.5 \%$ of Kenyans are Christians (Daily Nation, 2010 September). In the year 2008, I conducted research on the Anglican Church of Kenya (ACK). The findings of this research were that the ACK was experiencing tremendous numerical growth, about $6.7 \%$ per annum. The study also projected that if the same trend is maintained, about $18 \%$ of Kenyans will be Anglicans by the year 2030 . The year 2030 is important because it is the year which Kenya plans to be fully developed (Nkonge 2008:63).

In this paper, we shall look at the four main Christian denominations in Kenya namely, the Roman Catholic Church (RCC), the Anglican Church of Kenya (ACK), the Presbyterian Church of East Africa (PCEA) and the Methodist Church in Kenya (MCK) to serve as examples to help us determine what is happening in Kenya and the rest of Africa. I have chosen these churches because they are the strongest denominations in Kenya today. The table below shows the estimate adherents of these churches in the year 2010 and their percentages in relation to the country's population which according to the 2009 population census results released in 2010 is about 38.6 million (Daily Nation, 2010 September). These figures are calculated from the churches' membership returns available at their headquarters in Nairobi.

Table 1- Adherents in the selected churches

\begin{tabular}{|l|l|l|}
\hline Churches & Adherents & Percentage \\
\hline Roman Catholic Church & $9,028,525$ & 23.3 \\
Anglican Church (ACK) & $3,960,587$ & 10.3 \\
Presbyterian Church (PCEA) & $2,835,000$ & 7.3 \\
Methodist Church (MCK) & $1,150,000$ & 2.9 \\
Total & $16,974,112$ & 43.8 \\
\hline
\end{tabular}

According to the 2009 population census, Christians constitute about $82.5 \%$ of Kenyan population. If the main denominations in Kenya (RCC, ACK, PCEA and MCK) enjoy a following of about 43.8 $\%$ of Kenya's population as the table above indicates, then it means that the remaining churches such as the African Independent Churches (AICs), the Pentecostal Churches, the New Religious Movements and others form about $38.7 \%$ of Kenya's population. So the RCC, ACK, PCEA and MCK are the strongest denominations in Kenya. Kenya is predominantly a Christian country and church growth in this country cannot be understated (Daily Nation, 2010 September).

One question we need to ask ourselves is, if the church is growing so rapidly in Kenya, has it been able to produce reliable church leaders to match this growth? Can we be proud that we are a rapidly growing Church? Are the church leaders enough and well-equipped to manage the affairs of this growing Kenyan Church? This is our main concern in this paper. To answer some of these questions we shall start by looking at the estimate number of clergy (and their qualifications) currently serving in the denominations which we have selected. This will tell us what is exactly happening in these churches and the church in Africa in general.

\subsection{Number of clergy serving in the RCC, ACK, PCEA, MCK and their qualifications}

As we have already elucidated, reliability in this paper entails looking at whether the church in Kenya has enough well qualified church leaders to lead it in this challenging century. Reliable leadership here means that pastoral leaders are available whenever needed by their flock to offer spiritual help and guidance and that they are well-trained to meet the various challenges facing the African society today. In 1950s, Oliver (1952: 289, 291-2) while describing the situation in the African Church was startled that churches in East Africa and Africa as a whole had failed to allure the elite Africans into their leadership. This is in contrast to the 
initial decades of colonialism when the literate Africans became either chiefs or churchmen. With the development of secondary education and the growth of secular opportunities the churches began to be left behind in the competition for the best educated Africans. The situation aggravated with the beginnings of higher education in Africa when most of the best educated people opted for secular employment. Oliver concludes that 'the church led by peasant priests risks disintegrating at the centre while expanding at the circumference.' In other words, the Church may expand numerically but if it lacks reliable leadership then it cannot go far. In 1970s, Mbiti (1971:177) was perturbed by the fact that in spite of the rapid growth experienced by the African Church in terms of the numerical growth, the church still lacked qualified leaders in its leadership and quality theological discernment. He lamented that "The church in East Africa and Africa as a whole as a whole has come into existence and has grown evangelistically and not theologically". The church that was experiencing a tremendous numerical growth had little to show for it in terms of the theological output. The Church in Africa had grown extensively in terms of members, sponsored schools, clinics, dispensaries and other physical facilities, yet the pastor remained the least educated person in the educated section of the society. He therefore lamented that 'the Church in East Africa and Africa as a whole has come into existence and has grown evangelistically and not theologically.' In the 1980s, Mugambi (1984:1-4) raised a similar concern. Till then, the Church in Africa could not attract the African elite into its leadership. The luscious well-paying secular jobs took the best educated Africans while the church which was perceived by many as a 'poor employer' was able to attract only the least educated Africans in its leadership.

We need to ask ourselves whether the situation today is different from what these scholars had observed. We have already seen that the church in Kenya is a growing church, experiencing remarkable numerical growth since its inception in the nineteenth-century. In this section, we need to find out whether the Church in Kenya is producing enough and qualified leaders to match this rapid growth. Can we be proud that we have a rapidly growing Church in Kenya? The success of any organization, the Church included, largely depends on its ability to produce enough and well-qualified, reliable leaders.

\subsection{Estimate Number of Clergy Serving in Our Selected Churches}

Table 2 below shows the estimate number of clergy serving in the mainline churches in Kenya in the year 2010. The number of clergy serving in these churches has been acquired from the headquarters of these denominations in Nairobi and also from their directories. The clergy working in institutions/places other than in the parishes are not included. For the Catholic Church only the diocesan clergy are considered.

Table 2- The Number of clergy working in the selected churches

\begin{tabular}{|l|l|l|l|}
\hline Denomination & No. of Christians & No. of Clergy & \multicolumn{1}{|c|}{$\begin{array}{l}\text { Clergy per } \\
\text { Christians Ratio }\end{array}$} \\
\hline Roman Catholic & $9,028,525$ & 1,479 & $1: 6104$ \\
ACK & $3,960,587$ & 1,555 & $1: 2547$ \\
PCEA & $2,835,000$ & 613 & $1: 4625$ \\
MCK & $1,150,000$ & 247 & $1: 4656$ \\
\hline
\end{tabular}

Figures in this table show the dismal situation facing the church in Kenya today. In table 1, we showed that the church in Kenya is experiencing remarkable numerical growth. The ratio of clergy per Christians in table 2 is, however, worrying. There are very few pastors serving the large 
and growing population of Christians in Kenya today. Figures in table 2 show that in the Roman Catholic Church (RCC) one priest takes care of the spiritual needs of about 6100 Christians and in the Protestant churches one pastor serves about 2500, 4600 and 4700 Christians in the ACK, PCEA and MCK respectively. The question we should ask ourselves is how one pastor can effectively nurture such a large flock without some of them dying of hunger or thirst. Is it practically possible for one pastor/ priest to effectively satisfy the spiritual needs of 6100, 2500, 4600 or 4700 'sheep' without some of them going astray? The Gospel of John (1:1-5) gives an illustration of a shepherd and his flock whereby it says that (NIV),

The sheep listen to his voice. He calls his own sheep by name and leads them out. When he has brought out all his own, he goes on ahead of them and leads them out.

This text refers to Jesus Christ who is a very reliable shepherd of his flock. Reliable leadership entails that the shepherd knows his sheep by name including the old, young, weak, strong, sick and so on. This is only achievable if he/she is near them. If he/she is close to them then he/she is aware of all the challenges they are facing. In his study of the Anglican Church of Kenya, the author noted that although the ACK had a membership of about 3,711,890 adherents in the year 2008, only about 1,565,056 (42\%) Anglicans attended the church services regularly (active members). The remaining 2,146,839 (58\%) members were just Anglicans by name. He attributed this to, amongst others, a lack of enough pastors to serve the rapidly growing Anglican Church in Kenya. He concluded that 'A situation whereby $58 \%$ of the church members are not taken care of spiritually is a dangerous one' and so called on the ACK's leadership to wake up and address the situation without further delay' (Nkonge 2008:64). This is basically what is happening in all the African churches. The African Church is growing remarkably but it lacks enough leaders to match this growth as is clearly exemplified by the Kenyan situation.

This may explain why some Christians keep on moving from one denomination to another in search of spiritual nourishment. Currently, the ACK Diocese of Meru where I was born, brought up and ordained is among the smallest dioceses in the ACK. It has only roughly 12,872 members of which the majorities (about 95\%) are defectors from other denominations mainly the PCEA, MCK and RCC. ${ }^{2}$ In December 2010, I conducted research in the diocese to ascertain why some Christians had defected from their original churches such as the RCC, PCEA and the MCK to join the ACK. I interviewed 28 ACK members asking them why they had preferred the ACK to their original churches. Out of these 28 members, 23 (82.1\%) cited poor leadership in their original churches as the main cause of their defection. Asked to explain further, 17 (77.3\% of those who had cited poor leadership) said that they felt segregated because they had nobody to share their problems with as their pastors were inaccessible. Interestingly, 11 (39\% of those interviewed) confessed that they were considering defecting to other churches because the ACK was still not meeting their spiritual needs. In this case therefore, success in leadership is gauged in terms of availability of the pastors. Some churches make it very hard for Christians to have access to their bishops or pastors. At times, the pastor may be willing to listen to all his/her flock but it becomes difficult due to the large numbers he/she is handling. A bishop or a pastor who always insists on appointments before his flock can see him/her is bound to fail. Table 2 clearly indicates that the church in Kenya has a real problem due to lack of enough clergy to lead it in spite of its rapid growth. A shepherd is a friend of all and can only claim to know his sheep if he knows their needs. Looking at the ratio of clergy per Christians, one wonders whether one priest/pastor can effectively nurture such a large group without some of the flock getting lost. The challenges of

2 The dominant denominations in Meru are the Roman Catholic Church (RCC), PCEA and MCK. The ACK is new having been started in 1969 as compared to RCC in 1913, PCEA in 1910 and MCK in 1910. 
the twenty-first century are immense and call for a pastor/priest who is quite near to his/her sheep so that he/she can understand them and their needs. Such a pastor is able to meet the spiritual needs of his Christians. Therefore, although the Church in Kenya is growing rapidly, it does not produce enough leaders. One may ask why the growth continues even if there are not enough pastors.

In this regard the important influence of other ministries within the church in Kenya and Africa as a whole need to be recognized. The ministry of the laity has played a significant role in the growth of the church in Kenya and the rest of Africa. For instance, the structural organization of the Catholic Church is unique. Apart from the priests, there are other trained church leaders entrusted with the spiritual welfare of the Catholic congregations and parishes. These include Brothers, Sisters and Catechists. Therefore, although the priests are few, other church leaders play a significant role in shepherding and evangelization. For example, by the end of the year 2009, the Catholic Church had about 7,499 catechists (Catholic Church Directory 2009). Other denominations have a similar arrangement. The ACK has lay leaders and evangelists; the PCEA has church elders and evangelists and the MCK has accredited preachers and evangelists. But what makes the Catholic Church distinct from the Protestant churches is the fact that the Brothers, Sisters and Catechists are trained people. Sometimes Brothers and Sisters go through the same training with priests. What distinguishes them is the kind of services they offer. In the Protestant churches the lay leaders, church elders, preachers and evangelists are not necessarily trained people (see Mugambi 1995: 27-29).

However, those familiar with what is happening on the ground know that the success of the church in Kenya is mainly attributed to these lay people. It is therefore important that the church starts to think about them so that they are well-equipped for their ministry. The twenty-first century has come with numerous challenges and the society has become complex with many people who are well-educated. The success of the church depends on how well she is prepared to address the spiritual needs of this complex society. We cannot expect a lay leader, church elder or a preacher who is not well-trained to address the spiritual needs of a congregation which has professors, doctors, teachers, engineers and other professionals. The Kenyan Church needs to re-think its leadership development.

Some denominations have tried to address the problem of lay church leadership training by starting some institutions which mainly concentrate on training lay church leaders, but they are also facing a lot of challenges. For instance in 1958, the ACK started Church Army Africa to train Anglican evangelists and lay leaders. This however did not last for long as the trained evangelists were later ordained into priesthood but most of them subsequently left the ACK after which the members were once again served by untrained evangelists and lay leaders. The PCEA also has a lay training centre at Kikuyu which is currently not running and has no coordinator (PCEA Directory 2011). The Theological Education by Extension (TEE) program which was started by the Protestant churches as an ideal model of equipping lay church leaders is also not doing well. In the ACK TEE has died due to lack of finances (Nkonge 2008: 249).

The current crisis of insufficient pastors in the Kenyan Church may need to be addressed in other ways. It is very expensive to train and pay a pastor especially by the members of a congregation or a church which find it hard to survive due to limited resources. If a church wants to have well trained and well paid pastors, the number of members needed to finance these expenses, will be high, at least two thousand (Mugambi 2012). Therefore, instead of just thinking of adding more pastors, the church in Kenya as well as the whole of Africa may have to consider empowering the 'other ministries' through proper training. Ways and means should be devised to train lay leaders, evangelists, catechists, church elders and preachers. An important thing to note is that some of these church leaders are professionals in other areas and they do 
not have to be paid by the church. If the church therefore takes advantage of this and offer them sound theological training, they can offer very effective leadership to the church and the society.

\subsection{The academic Qualifications of the Clergy: An example from the ACK}

In the previous section, we have found out that the Church in Kenya is unable to produce enough church leaders to match its rapid growth rate. In this section we are asking whether the few church leaders produced by the Church are equipped well enough to lead the church and society in the twenty-first century. We are going to examine what is happening in the ACK, the largest Protestant Church in Kenya. This will be an indication of what is happening in the other churches in Kenya and the entire Africa. With the assistance of the Archbishop's office I conducted research to find out about the academic qualifications of the clergy currently serving in the ACK. The information we got is analyzed in Table 3 below.

Table 3: Academic Qualifications of the ACK Clergy

\begin{tabular}{|l|l|l|}
\hline Qualifications & No. of Clergy & Percentage \\
\hline Less than three years Theological Training & 218 & $14 \%$ \\
Certificate in Theology & 322 & $21 \%$ \\
Diploma in Theology & 753 & $48.4 \%$ \\
First Theological Degree (BA, BTh, BD etc) & 177 & $11 \%$ \\
Two theological Degrees (MA, MTh, M.Div, STM) & 61 & $4 \%$ \\
Doctor of Ministry (DMin) & 8 & $0.5 \%$ \\
Doctor of Philosophy (PhD, DTh) & 12 & $0.87 \%$ \\
A Secular Degree and some Theological Training & 4 & $0.26 \%$ \\
\hline Total & 1555 & $100 \%$ \\
\hline
\end{tabular}

\section{Observations}

Figures in Table 3 above show the following:

- Majority of the ACK Clergy (83\%) have Diploma and below qualifications, That is, Diploma$48 \%$, Certificate- $21 \%$ and less than 3 years Training- $14 \%$

- There are very few theological graduates in the ACK. Only 177 (11\%) have a first theological degree and barely $4 \%$ have two theological degrees.

- There is a visible lack of clergy with doctorates. Only $0.5 \%$ of clergy have Doctor of Ministry degrees and $0.87 \%$ has Doctor of Philosophy degrees.

- Very few ACK Clergy are professionals in other areas (only $0.26 \%$ ).

This example from the ACK serves to explain what is most probably happening in all the Kenyan churches and possibly in the rest of Africa too. The Kenyan society is growing very fast with many professionals such as doctors, lawyers, university lecturers, teachers, engineers, business people and farmers among others. Kenya's public and private universities and other institutions of higher learning are producing many graduates every year. The percentage of church leaders with degrees is declining considerably if compared to the growth of graduates in all other sectors of society. These graduates are the people who come to the church every Sunday to listen to their pastors' sermons. The trouble is that the sermons listened to by these people are coming from pastors who are, on average, poorly trained. The challenge of this is that few church members are willing to attend Sunday services regularly or are active church members. For instance, in the ACK, out of the total membership of about $3,711,890$, only about $1,565,056(42 \%)$ members 
attend the Sunday services regularly (active church members). This is mainly attributed to the boring and irrelevant sermons they receive from their poorly trained pastors (Nkonge 2008:64). The Church that has sponsored the best schools in Kenya and has started several universities is progressively failing to produce well-trained shepherds for its flock. ${ }^{3}$

The Church therefore needs to re-think its mission and ministry. The situation whereby majority of the clergy have diplomas or is less qualified is negative for a growing church with a growing number of well-educated people. It won't be able to handle the immense challenges of the twenty-first century. The case of the ACK whereby only 42 per cent of its followers attend the church services regularly can tell us a lot about the entire church in Africa (Nkonge 2008:64). People go to the church because they have various spiritual needs which need to be understood and need to be prophetically challenged. If this is not met and if respect for the pastor dwindles, they will leave the church disappointed. How could we expect them to continue attending the church services if sermons are of inferior quality? This is an exigent challenge calling for an urgent response. In concluding this section, we state the fact that there is lack of leadership in these matters in the Kenyan Church. Might this be a picture of what is happening in the whole of Africa?

\section{RECRUITING RELIABLE LEADERSHIP}

Kenya and the rest of Africa face numerous crises today. Authoritarianism, ethnic clashes, environmental degradation, poverty, hunger, corruption, diseases, internally displaced persons (IDPS), refugees et cetera have created a very desperate situation in Africa. As Archbishop Desmond Tutu puts it,

The picture is bleak and the prospect one of seemingly unmitigated gloom. It is as if the entire continent was groaning under the curse of Ham and was indeed in all aspects of the Dark Continent of antiquity. Africans may well ask: "Are we God's step children? Why has disaster picked on us so conspicuously?" We appear to be tragically unique in this respect (Ngara 2004:1).

No other time has there been such a need for reliable leadership in the entire African Continent as now. Most of the political leaders in Africa have failed to offer reliable leadership to their nations, leading to perpetual tension as recently witnessed in many African nations including Ivory Coast, Zimbabwe, Kenya, Egypt, Libya and many others. The Church has been relied upon to fill the leadership vacuum, but she has seldom acted decisively and prophetically. The performance of the Church in Africa is generally hampered by what Hans Küng cited several years ago. He asserted that (1974:29),

The Vatican ... vigorously defends social justice, democracy and human rights for the world outside, but continues to maintain internally an authoritarian style of Government, the inquisition, the use of public monies without public control. And the World Council of Churches ... concentrates its efforts for peace... without producing peace within its own sphere, between the Churches.

Küng was concerned about a church that was busy struggling to transform the 'world out there',

3 The best performing secondary schools in Kenya are those sponsored by the church such as Alliance High school, Starehe Boys' centre, Mangu High school etc. All the denominations which are our foci in this paper also have their own universities. 
yet she could not transform herself. Kenya's ACK Bishop Githiga (2001) argues strongly on the obligation of the church to fight societal vices such as tribalism, political dominance, nepotism et cetera. The biggest challenge however is how an authoritative, autocratic and tribally biased church can be a bulwark against authoritarianism, autocracy and tribalism. The church can only offer reliable leadership to the society if it is able to offer reliable leadership within itself. This can be achieved if the church recruits reliable leaders.

\subsection{The recruitment process}

The process of selecting candidates for ministerial formation or priesthood varies from one denomination to the other. The Catholic Church for example has a very organized system of selecting candidates for the priesthood. The process usually takes a long time. Those who join priesthood in the Catholic Church are sometimes selected very early while in secondary schools. After they join the seminaries, the candidates undertake some philosophical training which takes a minimum of two years. Once they are through, those who pass in philosophy are enrolled for theological studies which take a minimum of four years. Therefore, the minimum period one can take to train for priesthood in the Catholic Church is six years. Those who do well are recommended to go for further studies and others are posted to the parishes or other stations. There are several stages in training which ensures that at the end only the determined ones qualify to become priests. Those who do not qualify join other Church ministries with the aim of entering the ministry at a lower standard.

In the Protestant churches, the main factor considered for one to join the church ministry as an ordained priest or minister is the 'call'. The biggest challenge however has been to determine who has a 'call' and who has no 'call.' This is aggravated due to the high rate of unemployment in Kenya. In other words, how do you measure 'calling'? Some people have been joining the church ministry not because of the conviction that God is calling them, but because it is not easy to secure any other form of employment due to limited places. Civil servants often join the church ministry after retirement from the civil service so that they can at least have some work. ${ }^{4}$ In this case, church ministry has been a life-buoy for those who failed in their secondary school examinations and those who are not ready to retire from the civil service.

Academic qualifications are not an absolute requirement when it comes to selecting candidates for training in the Protestant theological colleges. One should at least have a Form Four certificate. This minimum academic requirement is too low. For instance, while the minimum requirements for a diploma certificate in the public and private universities and other Government tertiary colleges is aggregate C in O-levels (Kenya Certificate of Secondary Education), in most of the theological colleges, the minimum requirements for a diploma in theology is a D+ and a letter of recommendation from the church leader. This has greatly degraded the quality of theological education in Kenya.

Complementing low academic qualifications of those entering theological studies is the lack of adequate qualifications for the lecturers entrusted with the work of preparing church leaders in the theological colleges. The author's research into this matter focused on the academic qualifications of the lecturers teaching in the ACK provincial theological colleges. It showed that of the twenty lecturers teaching in the five ACK Provincial Theological Colleges, namely, St. Andrews, St. Paul's, St. Philip's, Bishop Hannington and Berea, only two had doctoral degrees. Of these two, one is an expatriate. Those with Masters Degrees were thirteen while the remaining five had first theological degrees. A situation whereby the theological colleges which are charged with the responsibility of preparing leaders for the African Church lack lecturers with doctorates does tell a lot about the future of such a church. Nkonge (2008:197) comments on this and says that,

4 The retirement age of civil servants is 60 years while in the church it is 65 years. 
In a situation where the church lacks sufficient and well-qualified personnel involved in leadership training, the mission of that church is affected. This is because the leaders prepared in the theological colleges cannot be relied upon to offer effective leadership to a church characterized by numerous challenges especially in this century. Such leaders are not relevant as they cannot interpret the Gospel of Christ to suit the changing needs of the society.

If the church leaders who are expected to help the African society are not enough and not well qualified and equipped, it means that such leadership cannot be relied upon to meet the needs of the afflicted African people. The process of the recruitment of church leaders therefore needs serious attention if the church in Kenya and the rest of Africa intends to survive in this rapidly changing century. Church ministry should not be seen as a place where those who never make it in life take refuge. It is important to consider whether one is called to serve God as a priest or minister, but it is equally important to get academically well-trained persons to serve the church.

\section{TRAINING FOR RELIABLE LEADERSHIP}

One question that needs to be asked is 'Are leaders born or made?' The answer to this question depends on one's perspective. To some people leadership is inborn as was the case with African traditional society or Judaism (see Githiga 200:1). We however need to be careful because although leadership in the African Traditional Society was mainly hereditary, there were some leadership skills that one had to learn from his father or other leaders before he took over the leadership of the clan or community. Even in the Old Testament, leadership required a lot of training. For instance, Moses had to learn many skills in the wilderness as he worked for his father in law (see Exodus 2:15-3:1). Similarly, King David may have learnt a lot from King Saul's palace where he was always called to entertain the king (1 Samuel 16:14-23). In the wilderness, he also acquired many leadership traits such as courage, determination, war skills et cetera as he took care of his father's flock (1Samuel 16: 11; 17:15 NIV).

Leadership may be an inborn gift but one has to learn it (see Githiga 2009:2). An important thing to note is that the church is an organization of Christian believers. As such, she needs reliable leadership just as other organizations. For any organization to succeed in achieving its goals it needs to have reliable leadership. Mugambi and Nkonge point out that the major business of the church on earth is to be in mission (Mugambi 1989:101; Nkonge 2004:100). This mission cannot be successful if there are too few well-trained reliable leaders. Stuckelberger and Mugambi (2005:12) argue that leaders are available in abundance, but responsible leaders are rare and hard to find. They feel that this responsible leadership entails good management and stewardship. Gitari (2005:206) elucidates that responsible leadership involves servant hood, stewardship, good administration, evangelism, quest for just social structures and promotion of national unity. The leadership called for by Stuckelberger, Mugambi and Gitari is tantamount to what we are referring to as reliable leadership in this paper. If the leader is responsible, then those led will rely on him/her and his/her leadership.

It is therefore clear that although leadership is a gift, we need to train reliable and responsible leaders. The theological colleges and the curriculum used to prepare church leaders are indispensable tools in this process. Chilver (1999:129) denotes that the future of the church is determined by its theological colleges. He asserts that "If theological colleges veer to the left with so many doubts about the authority of the scripture, the church in time will be so much affected." Nkonge (2008:129) contends that if theological colleges produce 'half baked' church 
leaders, then the future of the church in which they are to offer effective leadership is tainted.

\section{CONCLUSION}

More than ever before the Church in Kenya and the rest of Africa are in dire need of reliable leaders to guide it morally, ethically and missionaly. The development of leaders through training therefore needs close scrutiny. New models must be devised to help church leaders (both clergy and laity) in their theological reflections so that they are in a position of effectively proclaiming the Gospel of Christ to the currently rapidly changing African society.

\section{BIBLOGRAPHY}

Barrett, D 1982. World Christian Encyclopedia: A Comparative Survey of Churches and Religions in the Modern World, AD 1900-2000 Nairobi: Oxford University Press.

Baur, J 1990. The Catholic Church in Kenya Nairobi: St. Paul Publications

Catholic Church in Kenya Directory, 2009.

Chilver, A 1999. The Spiritual Formation in the Theological Colleges. Africa Journal of Evangelical Theology, Volume 18.2.

Church Leaders Oppose New Draft Constitution http://nairobiwantedinafrica.com/news 5/5/2010

Daily Nation 2010, September 1.

Gitari, D 2005. Responsible Leadership Nairobi: Acton.

Githiga, G 2001. The Church as the Bulwark against Authoritarianism Nairobi : Uzima.

Githiga, G 2009. Effective Church Leadership Nairobi: Uzima.

Hendriks, J 2006. Sustainable Seminaries, Reliable Leadership: The Net ACT Story 2000-2010. http:// academic.sun.ac.za/netact/PAPER-TEA-LIMURU 20 AUG 2010.pdf.

Jenkins, Philip. 2002. The next Christendom: The Coming of Global Christianity. Oxford: Oxford University Press.

Kenya: Church Leaders Reject the New Law. http://allafrica.com/stories 2/4/2010

Kenya Gazette, 2010. 'Independent Electoral and Boundaries Referendum Results, Notice No. 10019. Vol.

CXII-No. 84, 23 August'.

Küng, H 1974. On Being a Christian. Glasgow: Collins.

Mbiti, J 1971. New Testament Eschatology in an African Background. London: London University Press.

Mumo, P 1997. A Study of Theological Education in African Inland Church, Kenya: Its Historical

Development and its Present State. Unpublished PhD Thesis, Nairobi: University of Nairobi.

Mugambi, Jesse Interviewed by the author on 31 March 2012, at Nairobi.

Mugambi, JNK 1989. The Biblical Basis for Evangelization. Nairobi: Oxford University Press.

Mugambi, JNK 1995 From Liberation to Reconstruction. Nairobi:EAEP

Ngara, E 2004. Christian Church Leadership. Nairobi: Pauline's Publication.

Nkonge, DK 2005. A Study of the Anglican Church in Meru: Challenges encountered in evangelization. Unpublished MA Thesis. Nairobi: University of Nairobi.

Nkonge, DK 2008. Leadership Training for mission in the Anglican Church of Kenya. Unpublished PhD

Thesis, Pretoria: University of South Africa.

Oliver, R 1952. The Missionary factor in East Africa London: Longmans.

Presbyterian Church of Kenya (PCEA) Directory, 2011.

Richardson, A 1969. A Dictionary of Christian Theology London: SCM

Silo Breaker Star 2010, August 9. http://www.silobreaker.com.

Stuckulberger, C and Mugambi, JNK 2005. Responsible Leadership Nairobi: Acton

Waruta, D 1989. The Church as a teaching community in Christian Mission and Social Transformation, JNK Mugambi (ed) Nairobi. 


\section{KEY WORDS}

Reliable leadership

African church

Recruitment

Effective training

Contact details:

Dr Dickson Nkonge Kagema

Chuka University College,

Faculty of Arts and Humanities,

P.O Box $109-60400$ Chuka,

Kenya.

E-posadres: dicknkonge@gmail.com

Prof HJ Hendriks

Fakulteit Teologie

Universiteit van Stellenbosch

Privaatsak X1

7602 MATIELAND

Kantoor: 0218083260

Huis: 0218866034

Sel: 0737726706

E-posadres: hjh@sun.ac.za 